\title{
CHREMATONYMS IN THE PROFESSIONAL DISCOURSE OF THE NUCLEAR AND SPACE INDUSTRY
}

\author{
Natalya V. Yudina \\ Financial University under the Government of the Russian Federation, Moscow, Russia \\ Nataliya B. Feldman \\ Vladimir State University named after A.G. and N.G. Stoletovs, Vladimir, Russia; \\ Vladimir Information Center of Nuclear Energy, Vladimir, Russia
}

\begin{abstract}
The article focuses on studying chrematonyms in nuclear and space industry professional discourse. The analysis of 734 Russian, English, Italian, French, German, Polish and Japanese lexemes nominating spacecraft, spaceships, nuclear reactors and nuclear research facilities resulted in discovering three common ways in the process of generating and functioning of chrematonyms in the professional discourse, including a lexico-semantic nomination (formed by means of onimization of appellatives, transonymization of personal and precedent names, toponyms, chrematonyms and cosmonims, deonimization); the word-formation considers the sound, syllabic and mixed abbreviation, as well as the formation of compound words; the syntactic method involves the formation of simple and complex substantive combinations of words. The authors conclude that chrematonyms as a class of onims have a specific linguistic meaning, affecting the semantic generation of the proper name in an inanimate object of material culture and emphasizing the unique and differential feature of the object and point to their specifically professional linguistic feature: motivation, derivative character, terminological unity, and frequency of usage. The research demonstrates the following special aspects of functioning of chrematonyms in the professional discourse: play on words, allusions and metaphors, ameliorative and deteriorative connotative meanings, which reflect non-typical processes for professional lexis and perform a peace-maintaining function of the language.
\end{abstract}

Key words: professional discourse, language for special purposes, chrematonyms, onimization, transonymization, nomenclature unit, personal precedent names.

Citation. Yudina N.V., Feldman N.B. Chrematonyms in the Professional Discourse of the Nuclear and Space Industry. Vestnik Volgogradskogo gosudarstvennogo universiteta. Seriya 2. Yazykoznanie [Science Journal of Volgograd State University. Linguistics], 2019, vol. 18, no. 3, pp. 227-238. (in Russian). DOI: https://doi.org/10.15688/jvolsu2.2019.3.19

\section{ХРЕМАТОНИМЫ В ПРОФЕССИОНАЛЬНОМ ДИСКУРСЕ АТОМНОЙ И КОСМИЧЕСКОЙ ОТРАСЛЕЙ}

\author{
Наталья Владимировна Юдина \\ Финансовый университет при Правительстве РФ, г. Москва, Россия
}

\section{Наталия Борисовна Фельдман}

Владимирский государственный университет им. А.Г. и Н.Г. Столетовых, г. Владимир, Россия; Информационный центр по атомной энергии г. Владимира, г. Владимир, Россия

Аннотация. Статья посвящена описанию хрематонимов, представленных в профессиональном дискурсе атомной и космической отраслей науки и производства. На материале 734 русскоязычных и иноязычных (английских, индийских, итальянских, французских, немецких, польских, японских) наименований космических ап- 
паратов и кораблей, атомных реакторов и ядерных исследовательских установок показана общность процессов возникновения и функционирования хрематонимов в профессиональном дискурсе. Установлено, что в разных языках образование хрематонимов осуществляется тремя способами: лексико-семантическим (онимизация апеллятивов, трансонимизация личных и прецедентных имен, топонимов, хрематонимов и космонимов, деонимизация), словообразовательным (звуковая, слоговая, смешанная аббревиация, образование сложных слов), синтаксическим (образование простых и сложных субстантивных словосочетаний). Отмечены присущие анализируемому языковому материалу специфические черты профессиональной лексики: вторичность, системность, мотивированность и относительная ограниченность использования. Показаны особенности употребления хрематонимов в профессиональном дискурсе атомной и космической отраслей науки и производства: охарактеризованы случаи языковой игры, появления литературных аллюзий и метафор, формирования мелиоративных и пейоративных коннотативных значений. Перечисленные особенности функционирования хрематонимов отражают несвойственные для профессиональной лексики процессы и одновременно способствуют реализации миросозидающей, или ориентирующей, функции языка.

Ключевые слова: профессиональный дискурс, язык для специальных целей, хрематоним, онимизация, трансонимизация, номенклатурная единица, личное прецедентное имя.

Цитирование. Юдина Н. В., Фельдман Н. Б. Хрематонимы в профессиональном дискурсе атомной и космической отраслей // Вестник Волгоградского государственного университета. Серия 2, Языкознание. 2019. - T. 18, № 3. - C. 227-238. - DOI: https://doi.org/10.15688/jvolsu2.2019.3.19

\section{Введение}

Российские исследователи современного ономастического пространства проводят разыскания в рамках общей теории имени собственного [Рут, 2003; 2015; Суперанская, Подольская, Васильева, 2009; Супрун, 2011] и отдельных ее разделов: антропонимики [Феоктистова, 2016], топонимики [Березович, 2010] и др. Однако ономастические единицы в профессиональном общении остаются еще малоизученными.

Профессиональный дискурс реализуется в первую очередь через использование языка для специальных целей (далее - ЯСЦ), выступающего в качестве средства организации профессионального взаимодействия и социальной коммуникации в профессиональной среде. Изучением ЯСЦ как лингвистического феномена занимались Е.С. Кубрякова [Кубрякова, 2004; 2009], В.М. Лейчик [Лейчик, 2009б], А.В. Суперанская [Суперанская, 2009], Э.А. Сорокина [Сорокина, 2016], Т.Н. Хомутова [Хомутова, 2008] и др. Е.С. Кубрякова, в частности, отмечает, что язык в целом характеризуется дихотомией когниции и коммуникации, но при этом когнитивные и коммуникативные задачи связаны с реализацией одной из функций языка - ориентирующей, или миросозидающей [Кубрякова, 2009, с. 7]. Язык для специальных целей предназначен, по мнению Т.Н. Хомутовой, для обеспечения эффективности коммуникации специалистов в конкрет- ной области [Хомутова, 2008, с. 98]. Лексическое ядро ЯСЦ, его центр составляют термины. Периферия лексического поля ЯСЦ формируется профессионализмами и жаргонизмами [Сорокина, 2016, с. 170], а также единицами, возникающими в результате онимизации, трансонимизации, деонимизации профессиональной и терминологической лексики, в частности хрематонимами, которые, помимо лексико-семантического, образуются словообразовательным и синтаксическим способами.

Исследование, результаты которого обобщены в статье, посвящено изучению формирования и функционирования хрематонимов в профессиональном дискурсе на примере лексики атомной и космической отраслей. Обе отрасли активно развиваются начиная со второй половины XX в. и отличаются разработкой уникальных аппаратов и механизмов, в большинстве своем получивших собственные имена. Для создания космических кораблей и аппаратов, ядерных реакторов и разного рода установок требовались прорывные научные решения и технологии. Реализация этих масштабных проектов сопровождалась необходимостью соблюдения секретности, и само назначение создаваемых аппаратов и механизмов не предполагало (и не предполагает) их массового серийного выпуска, как, например, это происходит со станками, автомобилями и другими сложными технологическими устройствами. Возникновение онима вместо характеризующего наименования у объектов, по 
мнению М.Э. Рут, определяется социальной потребностью в присвоении собственного имени объекту [Рут, 2003, с. 122]. В случае с механизмами и устройствами, созданными в атомной и космической отраслях, на наш взгляд, эта социальная потребность обусловлена секретностью разрабатываемых технологий в сочетании с тенденцией экономии языковых средств: оним, чаще всего однословный, для называния конкретного уникального предмета более удобен, чем многословный термин или аббревиатура как сокращение сложного наименования. Кроме того, присвоение механизму собственного имени, которое является мотивированным только для представителя соответствующей отрасли, сближает этот оним с профессиональной лексикой, демонстрируя относительную узость употребления.

Актуальность предлагаемого исследования заключается в недостаточной изученности хрематонимов, функционирующих в профессиональном дискурсе. Кроме того, рассматриваемые нами единицы не подвергались специальному системному описанию, на что указывает А.В. Суперанская с соавторами [Суперанская и др., 2009, с. 30].

Проблематика нашего исследования определяется тем, что при строгости, системности и упорядоченности ЯСЦ в российской и зарубежной практике обнаруживается возможность для лингвотворческой деятельности современной языковой личности. Вследствие этого хрематонимы в профессиональном дискурсе демонстрируют нехарактерные для ЯСЦ процессы: языковую игру, использование литературных аллюзий и метафор, формирование коннотативных значений. Как отмечает А.В. Суперанская, при переходе имени нарицательного в имя собственное редуцируются в первую очередь «эмоциональные обертоны» [Суперанская, 2009, с. 246].

Указанные процессы иллюстрируют следующую языковую тенденцию: на процесс наречения, представляющий собой акт выбора из имеющегося перечня имен либо «механического переведения нарицательного имени в ранг собственного» [Рут, 2003, с. 123], влияют экстралингвистические ресурсы, вследствие чего внутри системы ЯСЦ, предполагающей строгую регламентацию, возникают нехарактерные для нее языковые явления. Основным экстралингвистическим фактором выступают особенности номинатора - современной языковой личности, к которым относится, в частности, креативность, склонность к инновационным процессам и разрушению стереотипов [Юдина, 2010, с. 171], которые и приводят к использованию языковой игры, литературных аллюзий, выбору прецедентных имен и т. п. При этом важным условием становится общее для номинатора и реципиента культурное знание.

Согласно мнению Н.В. Подольской, под хрематонимом следует понимать «собственное имя предмета материальной культуры», возникающее вследствие исключительной ценности либо уникальности [Подольская, 1978, с. 161]. А.В. Суперанская определяет хрематонимы как отдельные высокоценные предметы [Суперанская и др., 2009, с. 30]. В настоящей статье термин «хрематоним» мы используем по отношению к именам собственным объектов, аппаратов, механизмов и устройств, разработанных атомной и космической промышленностью для реализации различных практических задач.

Анализируемый языковой материал включает имена собственные экспериментальных и исследовательских космических спутников, аппаратов и устройств, а также ядерных реакторов, устройств и механизмов, использующихся в атомной отрасли, разработанных в России и за рубежом, происхождение наименований которых достоверно установлено на основании анализа контекстов. Нами было проанализировано 117 русских единиц и 617 иноязычных единиц (английских, индийских, итальянских, немецких, польских, французских, японских), используемых в 1000 контекстов (300 контекстов, в которых употреблены 163 названия космических спутников и аппаратов, и 700 контекстов, в которых употреблено 571 название ядерных реакторов, энергоблоков и исследовательских установок). Источниками языкового материала послужили российские и зарубежные официальные сайты и информационные ресурсы, посвященные атомной и космической отраслям науки и промышленности (см. список источников; ссылки на источники даются только при интерпретации содержания термина). 


\section{МАТЕРИАЛЫ И СООБЩЕНИЯ}

\section{Способы образования хрематонимов}

Лексико-семантический способ образования хрематонимов в профессиональном дискурсе связан преимущественно с процессами трансонимизации и онимизации. По мнению А.В. Суперанской, трансонимизация является «одним из очень распространенных путей образования новых имен собственных всех разрядов» и происходит этот процесс как перенос известного имени в иной ономастический класс [Суперанская и др., 2009, c. 46]. Лексико-семантическим способом образовано 549 хрематонимов атомной отрасли и 147 хрематонимов космической отрасли. Классификация хрематонимов построена на основе процессов в семантике производящей лексической единицы (другого онима или апеллятива).

1. Онимизация апеллятивов ( 85 единиц). В этот процесс вовлечены существительные, разнообразные по значению и стилистической окраске:

1) существительные с общим значением 'исследователь, первопроходец, путешественник': исследовательские космические аппараты Ranger, Voyageur, Pioneer, Mariner;

2) отвлеченные существительные: марсоходы Opportunity, Curiosity;

3) существительные, обозначающие природные явления: космические аппараты Dawn, «Акаиуки»; корабли «Заря», «Восход», «Буран»;

4) существительные, обозначающие стороны света: корабль «Восток»; плавучая АЭС «Север»;

5) существительные, обозначающие космические объекты: пилотируемый космический корабль «Звезда»;

6) существительные, обозначающие устройства: космический аппарат «Зонд»; авиационно-космическая система «Спираль»;

7) названия цветов: критический стенд «Acmpa»; реактор CROCUS (Швейцария);

8) названия камней и минералов: установка «Azam»; реактор Celestin I (Франция); реактор SAPHIR (Швейцария); космический корабль «Алмаз»;

9) названия музыкальных произведений: исследовательские реакторы Masurca и Rhapsodie (Франция);
10) термины из квантовой физики: критический стенд «Квант»; фотохимическая установка «ФОТОН»;

11) многозначные слова: критический стенд «Дельта»; реактор «Гамма»; импульсный растворный реактор «Гидра»; исследовательские реакторы JEEP (Норвегия), VIPER (Англия);

12) жаргонизмы: антарктический реактор Nukey poo.

2. Трансонимизация онимов. В группу входят 15 единиц космической отрасли и 397 единиц атомной отрасли:

1) трансонимизация антропонимов:

a) личные имена: реактор «Аннушка»; польские исследовательские реакторы Anna, Agata и Maryla, норвежский реактор NORA;

б) прецедентные личные имена:

- фамилии реально существовавших людей: автоматический космический аппарат «Галилео» (англ. Galileo); межпланетная станция «Магеллан»; плавучая АЭС «Академик Ломоносов»; реактор Enrico Fermi (Италия);

- личные имена мифологических, литературных и сказочных персонажей: автоматическая межпланетная станция «Улисс» (англ. Ulysses); автоматическая межпланетная станция НАСА «Юнона»; растворный реактор «Apгус»; индийский реактор Apsara reactor; российский реактор «Иван» - при отнесении хрематонима в эту группу мы опирались на информацию, зафиксированную в «Большом лингвострановедческом словаре», включающем в том числе имена фольклорных персонажей (Россия, с. 216-217);

2) трансонимизация топонимов: передвижная атомная энергетическая станция «Памир»; спускаемый аппарат «Фи́лы»» (англ. Philaelander). К этой же группе можно отнести и иноязычные хрематонимы - названия ядерных энергоблоков, установленных на зарубежных АЭС. Таких единиц более 350 ;

3) трансонимизация хрематонимов: автоматическая межпланетная станция «Розе́mma» (англ. Rosetta) (названа в честь знаменитого Розеттского камня);

4) трансонимизация космонимов: космические аппараты «Венера», «Луна», «Mapc», «Фобос»; бельгийский реактор $V E N U S$ (Венера) и английский реактор PLUTO (Плутон). 
3. Деонимизация. Под процессом деонимизации мы понимаем переход онимов в номенклатурные единицы и переход номенклатурных единиц в апеллятивы. Как отмечает В.М. Лейчик, номенклатурными знаками становятся названия космических кораблей, искусственных спутников и прочих устройств, выпускаемых сериями, и каждой последующей аналогичной модели присваивается порядковый номер [Лейчик, 2009б, с. 33]. В анализируемом языковом материале среди хрематонимов космической отрасли насчитывается 53 номенклатурных единицы советского периода и 31 зарубежная языковая единица, а также 115 номенклатурных единиц атомной отрасли:

1) переход онимов в номенклатурные единицы. Переход хрематонимов атомной отрасли, называющих зарубежные ядерные энергоблоки АЭС, в номенклатурные единицы происходит практически сразу же после начала постройки второго и последующих энергоблоков станции, которым присваиваются порядковые номера, добавляемые к имени-названию: аргентинские энергоблоки Atucha-1 - Atucha-3. Аналогичный процесс происходит с хрематонимами космической отрасли: аппараты «Венера-1» - «Венера16»; «Луна-1» - «Луна-28»; Mariner-1 Mariner-10; Pioneer-1 - Pioneer-11. Однако чаще всего этим характеристикам отвечают номинации зарубежных реакторных энергоблоков: Kozloduy-1, Diablo Canyon - 2, Donald C. Cook - 1. Они именуются по названию АЭС, на которой установлены, и сопровождаются порядковым номером. Имя собственное для АЭС образуется в результате процесса трансонимизации топонима, гидронима либо антропонима. Выбор топонима или гидронима обусловлен пространственной близостью, а антропонимы представляют собой имена реально существующих людей, внесших значимый вклад в строительство или развитие объекта. В русской лингвокультурной традиции серийные ядерные энергоблоки на АЭС не получают личных имен, а обозначаются порядковыми номерами, указывающими на хронологию строительства, с добавлением названия атомной электростанции, например: первый энергоблок Ленинградской $А Э С$;
2) переход номенклатурной единицы в апеллятив: токамак.

Словообразовательный способ создания хрематонимов представлен аббревиацией и словосложением (17 единиц атомной отрасли и 6 единиц космической отрасли). Нами не зафиксированы примеры буквенной аббревиации, что объясняется естественными языковыми законами: любое имя собственное ассоциируется с первичной языковой единицей, от которой было образовано, как на семантическом, так и на фонетическом уровне.

Представлены:

1. Аббревиация. Под аббревиатурным именем мы, вслед за В.И. Супруном, будем понимать производное имя собственное, образованное путем сокращения производящих слов [Супрун, 2011, с. 136]. К основным типам аббревиации у хрематонимов атомной и космической отраслей относятся:

1) звуковая аббревиация: американский искусственный спутник для исследования атмосферы Mapca MAVEN (от англ. Mars Atmosphere and Volatile EvolutioN); солнечные батареи SCARLET (Solar Concentrator Array of Refractive Linear Element Technologies); ядерные реакторы «МИР», Ewa, FREYA, Zoé;

2) слоговая аббревиация: автоматическая межпланетная станция «Вега» (от названия проекта «Венера - и комета Галлея»);

3) смешанная аббревиация: токамак (ток, камера, магнит, катушка); реактор «РУСЛАН»; канадский реактор The SLOWPOKE (Safe LOW-Power Kritical Experiment); американская автоматическая межпланетная станция «Мессенджер» (англ. Mercury Surface, Space ENvironment, GEochemistry and Ranging - MESSENGER).

2. Словосложение. Это нехарактерный способ деривации хрематонимов в профессиональном дискурсе. В нашем материале зафиксировано 3 языковые единицы атомной отрасли и 2 языковые единицы космической отрасли:

1) сложные слова со слитным написанием: установка гамма-излучения «Гаммарид»; автоматическая межпланетная станция «Cтардаст» (англ. Stardust - дословно 'звездная пыль');

2) сложные слова с дефисным написанием: установка для испытаний термоэмис- 


\section{МАТЕРИАЛЫ И СООБЩЕНИЯ}

сионных электрогенерирующих каналов «НOT-КОМПАС»; установка «РАСПЛАВ Salt»; автоматическая межпланетная станция «Кассини-Гюйгенс» (англ. Cassini-Huygens).

Особенность приведенных в этом разделе наименований заключается в том, что, будучи аббревиатурами по способу образования, они представляют собой значимое слово, которое по лексико-семантическому основанию также может быть включено в одну из групп (в частности, в группу апеллятивов либо прецедентных имен).

Синтаксическим способом образованы 10 хрематонимов космической отрасли и 5 хрематонимов атомной отрасли. Анализируемые комбинации являются субстантивными словосочетаниями с зависимым словом - определением, выраженным либо прилагательным, либо существительным в роли приложения:

1. Простые словосочетания (8 единиц): Deep Impact, Mars Express, Mars Odyssey, Mars Pathfinder, New Horizons, Venus Express, Eau lourde (дословно 'тяжелая вода'), Prototype à terre (дословно 'прототип на земле').

2. Сложные словосочетания (7 единиц): Deep Space 1, Mars Global Surveyor, Mars Reconnaissance Orbiter, Trace Gas Orbiter,
Chaufferie avancée prototype (Cар) ('продвинутый прототип котельной - колпачок'); Réacteur nouvelle génération (RNG) ('реактор нового поколения'); Réacteur à Haut Flux ('реактор высокого потока').

\section{Соотношение хрематонимов атомной и космической отраслей}

Соотношение русскоязычных и иноязычных хрематонимов в соответствии с вышеприведенной классификацией в лексике атомной и космической отраслей отражено в таблицах 1 и 2.

В анализируемом языковом материале самый продуктивный способ образования хрематонимов - трансонимизация топонимов. Продуктивность модели обусловлена традицией присвоения собственных имен зарубежным ядерным реакторам, установленным на АЭС. В космическом профессиональном дискурсе использование топонимов является непродуктивным способом образования хрематонимов.

В профессиональном дискурсе широко представлены хрематонимы, перешедшие в номенклатурные единицы. Их использование помогает сохранить уникальность и узнавае-

Таблица 1

\section{Количественная представленность способов образования хрематонимов космической отрасли}

\begin{tabular}{|c|c|c|}
\hline \multirow{2}{*}{ Рубрики классификации } & \multicolumn{2}{|c|}{ Количество анализируемых единиц } \\
\hline & Русскоязычные & Иноязычные \\
\hline \multicolumn{3}{|c|}{ Лексико-семантический способ } \\
\hline Онимизация & 8 & 40 \\
\hline Апеллятивы & 8 & 40 \\
\hline Трансонимизация & 5 & 10 \\
\hline Прецедентные имена & 0 & 8 \\
\hline Топонимы & 1 & 1 \\
\hline Хрематонимы & 0 & 1 \\
\hline Космонимы & 4 & 0 \\
\hline Деонимизация & 53 & 31 \\
\hline Номенклатурные единицы & 53 & 31 \\
\hline \multicolumn{3}{|c|}{ Словообразовательный способ } \\
\hline Аббревиация & 1 & 3 \\
\hline Звуковая аббревиация & 0 & 1 \\
\hline Слоговая аббревиация & 1 & 0 \\
\hline Смешанная аббревиация & 0 & 2 \\
\hline Словосложение & $\mathbf{0}$ & 2 \\
\hline Сложные слова & 0 & 2 \\
\hline \multicolumn{3}{|c|}{ Синтаксический способ } \\
\hline Словосочетания & 0 & 10 \\
\hline Итого & 67 & 96 \\
\hline
\end{tabular}


Н.В. Юдина, Н.Б. Фельдман. Хрематонимы в профессиональном дискурсе атомной и космической отраслей

\section{Количественная представленность способов образования хрематонимов}

атомной отрасли

\begin{tabular}{|c|c|c|}
\hline \multirow{2}{*}{ Рубрики классификации } & \multicolumn{2}{|c|}{ Количество анализируемых единиц } \\
\cline { 2 - 3 } Лексико-семантический способ \\
\hline Онимизация & $\mathbf{1 9}$ & $\mathbf{1 8}$ \\
\hline Апеллятивы & 19 & 18 \\
\hline Трансонимизация & $\mathbf{9}$ & $\mathbf{3 8 8}$ \\
\hline Личные имена & 2 & 4 \\
\hline Прецедентные имена & 5 & 32 \\
\hline Топонимы & 2 & 350 \\
\hline Космонимы & 0 & 2 \\
\hline Деонимизация & $\mathbf{1 5}$ & $\mathbf{1 0 0}$ \\
\hline Номенклатурные единицы & 15 & 100 \\
\hline \multicolumn{2}{|c|}{ Словообразовательный способ } \\
\hline Аббревиация & $\mathbf{6}$ & $\mathbf{8}$ \\
\hline Звуковая аббревиация & 5 & 4 \\
\hline Смешанная аббревиация & 1 & 4 \\
\hline Словосложение & $\mathbf{1}$ & $\mathbf{2}$ \\
\hline Сложные слова & 1 & 2 \\
\hline \multicolumn{2}{|c|}{ Стогогоссический способ } \\
\hline Словосочетания & 0 & 5 \\
\hline \multicolumn{2}{|c|}{} & $\mathbf{5 0}$ \\
\hline
\end{tabular}

мость именуемого объекта и одновременно указывать на принадлежность к определенной серии и очередность создания. Эта особенность наблюдается как в русскоязычной, так и в иноязычной традиции.

На основании приведенных в таблицах данных мы также можем сделать вывод о том, что продуктивным способом номинации в лексике атомной и космической отраслей является использование апеллятивов и личных прецедентных имен, включающих 2 подгруппы: личные имена реально существующих людей и имена мифологических персонажей.

Синтаксический способ образования хрематонимов в профессиональном дискурсе более характерен для иноязычной традиции.

\section{Функционирование хрематонимов \\ в профессиональном дискурсе}

С одной стороны, собственные имена, как справедливо отмечает А.В. Суперанская, сближаются с терминологической и специальной лексикой благодаря факту вторичности их специального использования [Суперанская, 2009 , с. 32-36], а также благодаря функции знака-обозначения, которую выделяет у терминов В.М. Лейчик [Лейчик, 2009а, с. 26] и которую исследователи называют одной из основных характеристик имен собственных. С другой стороны, коммуникативная, апеллятивная, экспрессивная и дейктическая функции собственных имен [Суперанская, 2009, c. 272-273] наряду с воздействием экстралингвистических факторов обусловливают возникновение нехарактерных для ЯСЦ и профессионального дискурса явлений: языковой игры, литературных аллюзий и метафор, формирования особых коннотативных полей. Рассмотрим указанные процессы на примере проанализированного языкового материала.

1. Языковая игра реализуется посредством следующих приемов:

1) использование многозначных слов для наименования установок и механизмов: критический стенд «Дельта»; реактор «Гамма»; импульсный растворный реактор «Гидра»; исследовательские реакторы JEEP (Норвегия), VIPER (Англия). Этот прием позволяет подчеркнуть уникальность объекта, выделить его из ряда других и одновременно сохранить секретность технологии, присвоив немотивированное название в виде многозначного слова, чтобы исключить семантическую соотнесенность. Теми же причинами можно объяснить образование хрематонимов от названий 


\section{МАТЕРИАЛЫ И СООБЩЕНИЯ}

цветов, камней, минералов и музыкальных произведений, терминов из смежной отрасли. Имена не мотивированы, но при этом у людей, причастных к созданию и эксплуатации этих устройств, существует точная соотнесенность онима и механизма, обозначаемого этим онимом;

2) созвучие слов, рифма. Названия английских исследовательских реакторов $L I D O$ ('открытый плавательный бассейн') и $D I D O$ ('шалость, проказа'), построенных примерно в одно и то же время, рифмуются, отличаясь всего одним звуком.

2. Появлению в профессиональном дискурсе литературных аллюзий и метафор способствуют:

1) использование личных прецедентных имен, представляющих собой имена мифологических и литературных персонажей. Согласно мнению Д.Б. Гудкова, под прецедентными именами следует понимать группу внутри индивидуальных имен, выделяющуюся на основании особенностей их функционирования в дискурсе в качестве культурного знака, символа [Гудков, 1999, с. 62]. В.В. Красных называет прецедентное имя результатом «эмоционально-образного восприятия уникального лица-персонажа», обусловленным культурой и являющимся общим достоянием [Красных, 2016, с. 276]. Так, хрематоним «РУСЛАН» возник как аббревиатура. В книге воспоминаний В.Н. Новоселова приводятся такие варианты расшифровки: реакторная установка $с$ лантаном или реакторная установка с литиево-алюминиевым наполнением (Новоселов, Носач, Ентяков, с. 133). Анализируемый хрематоним совпадает с прецедентным именем собственным, отсылающим русскоязычного читателя к поэме А.С. Пушкина «Руслан и Людмила». Возможно, в связи с воздействием вышеуказанного прецедентного текста вслед за именем реактора «РУСЛАН», запущенного в 1979 г., появилось и имя «Людмила», которым назвали реактор «ЛФ-2», построенный в 1988 году;

2) подбор хрематонима, передающего характер / способ работы устройства, механизма. Например, название реактора The SLOWPOKE (Safe LOW-POwer Kritical Experiment) на тепловых (медленных) нейтронах переводится как «тугодум», а ошибка в слове Kritical допущена авторами названия намеренно (правильный вариант написания Critical), для подчеркивания ассоциативной связи между получившимся именем реактора и способом его работы;

3) использование для образования хрематонимов космической отрасли апеллятивов с общим значением 'исследователь, первопроходец, путешественник': Ranger, Voyageur, Pioneer; отвлеченных существительных: Opportunity, Curiosity; природных явлений: Dawn, «Акаиуки». Этот прием формирует метафору, передающую обширность изучаемого пространства, исследовательский дух, движение вперед в познании неизведанного;

4) выбор имени, создающий прецедентную ситуацию. Автоматическая межпланетная станция НАСА «Юнона» (также «Джуно», от англ. Juno, Jupiter Polar Orbite) создана для изучения Юпитера. Соответственно, выбор имени «Юнона» отсылает нас к древнеримскому варианту древнегреческого пантеона богов, где Юнона ревнивая жена Юпитера, которая контролирует и проверяет его.

3. Выражение отношения говорящего к объекту:

1) мелиоративное коннотативное значение создается за счет появления у объекта дополнительного неофициального имени. Ярким примером этого служит имя реактора «Аннушка». Употребление деминутива в профессиональном дискурсе, для которого нехарактерно функционирование слов с эмоциональной окраской, формирует особое коннотативное поле: участники атомного проекта в своих воспоминаниях о строительстве и эксплуатации «объекта А», как первоначально называли этот реактор, используют слова с мелиоративной коннотацией: уранграфитовый реактор $A$, или, как его иногда любовно называют, Аннушка (Бурдаков, с. 97); С тех пор первенец атомной промышленности стал называться «Аннушкой». Это ласковое женское имя всем понравилось, быстро распространилось и прижилось (Трякин, c. 384). Приведем еще один пример: межпланетная космическая станция «Акаиуки» (яп. あかつき 'рассвет', 'утренняя заря') официально известна как проект PLANET-C. Появление у неодушевленных предметов с офици- 
альным наименованием дополнительных неофициальных имен выполняет две функции, как считает О.В. Махниборода: усиление идентификации объекта и выражение субъективного отношения говорящего к этому объекту [Махниборода, 2007, с. 155];

2) имя-жаргонизм антарктического реактора Nukey роо демонстрирует возникновение пейоративной коннотации. Происхождение этого имени связано с частыми утечками радиации у реактора: A reactor at Antarctica's McMurdo Station that operated through the 1960s was nicknamed "nukey poo" because of its poor performance and reliability (though some reports simply point to "frequent radioactive leaks") (The Story of Nukey Роо). В некоторых комментариях реактор называют мальчиком: The video of Nuclear Boy and his stinky роо - и используют жаргонные и стилистически сниженные слова (stinky poо, дословно 'вонючая какашка'), образно описывающие результат утечки радиоактивного топлива и одновременно выражающие негативное отношение говорящего к этому процессу, дополняет пейоративную коннотацию хрематонима.

Наряду с перечисленными особенностями хрематонимов в профессиональном дискурсе в нем отражаются принципы именования, демонстрирующие характеристики профессиональной лексики: вторичность, системность, мотивированность и относительную ограниченность использования.

\section{Выводы}

Анализ хрематонимов атомной и космической отраслей на материале английского (76,3\%), итальянского (1,2\%), немецкого $(0,5 \%)$, польского $(0,7 \%)$, русского (16\%), французского (2,7 \%), хинди (1\%), японского $(1,6 \%)$ языков показал, что к хрематонимам обеих отраслей можно применить единую классификацию, свидетельствующую об общих законах возникновения и функционирования хрематонимов в профессиональном дискурсе.

На основании анализа нами были сделаны следующие выводы:

1. Хрематонимы как класс имен собственных, функционирующих в профессио- нальном дискурсе, обладают специфическим значением, в основе которого лежит уникальность объекта и его семантическая отнесенность, возникшая в результате трансонимизации. Этот вывод соотносится с исследованиями Е.С. Кубряковой и Т.Н. Хомутовой, в которых отмечены коммуникативная роль ЯСЦ в профессиональном дискурсе и ориентирующая функция языка, которую реализуют хрематонимы именно в результате возникновения специфического значения.

2. Способ образования хрематонима в меньшей степени влияет на его морфологические и лексико-семантические характеристики: даже будучи образованными способом звуковой либо смешанной аббревиации, хрематонимы в профессиональном дискурсе представляют собой значимое слово, соотносящееся с существующим антропонимом либо апеллятивом.

3. Образование хрематонимов в профессиональном дискурсе отличается использованием языковой игры, литературных аллюзий и метафор, формированием мелиоративных и пейоративных коннотативных полей, что отражает нехарактерные для профессиональной лексики процессы и одновременно реализует миросозидающую функцию языка. На примере функционирования хрематонимов также можно проследить присущие анализируемому языковому материалу специфические черты профессиональной лексики: вторичность, системность, мотивированность и относительную ограниченность использования.

\section{СПИСОК ЛИТЕРАТУРЫ}

Березович Е. Л., 2010. Русская топонимия в этнолингвистическом аспекте : Мифопоэтический образ пространства. Изд. 2-е, испр. и доп. М. : КомКнига. 240 с.

Гудков Д. Б., 1999. Прецедентное имя и проблемы прецедентности. М. : Изд-во МГУ. 152 с.

Красных В. В., 2016. Словарь и грамматика лингвокультуры. Основы психолингвокультурологии. М. : Гнозис. 496 с.

Кубрякова Е. С., 2004. Язык и знание : На пути получения знаний о языке : Части речи с когнитивной точки зрения. Роль языка в познании мира. М. : Яз. слав. культуры. 560 с. 
Кубрякова Е. С., 2009. В поисках сущности языка // Вопросы когнитивной лингвистики. № 1 (18). C. 5-12.

Лейчик В. М., 2009а. Терминоведение : Предмет, методы, структура. Изд. 4-е. М. : ЛИБРОКОМ. $256 \mathrm{c}$.

Лейчик В. М., 2009б. Люди и слова : Как рождаются и живут слова в русском языке / отв. ред. Г. В. Степанов. Изд. 2-е, испр. и доп. М. : ЛИБРОКОМ. $216 \mathrm{c}$.

Махниборода О. В., 2007. О классификации неофициальных дополнительных имен неодушевленных предметов // Известия Российского государственного педагогического университета им. А.И. Герцена. № 19 (45). С. 155-158.

Подольская Н. В., 1978. Словарь русской ономастической терминологии. М. : Наука. 198 с.

Рут М. Э., 2003. Номинация, наречение и имя собственное // Ономастика и диалектная лексика : сб. науч. тр. Екатеринбург : Изд-во Урал. ун-та. Вып. 4. С. 120-124.

Рут М. Э., 2015.Ономасиология? Мотивация? Семантика? Идеография? О классификациях имен собственных // Этнолингвистика. Ономастика. Этимология : материалы III Междунар. науч. конф. (г. Екатеринбург, 7-11 сент. 2015 г.). Екатеринбург : Изд-во Урал. ун-та. C. 231-233.

Сорокина Э. А., 2016. Язык для специальных целей как средство общения // Вестник Челябинского государственного университета. № 4 (386), вып. 100. С. 169-172.

Суперанская А. В., 2009. Общая теория имени собственного / отв. ред. А. А. Реформатский. Изд. 3-е, испр. М. : ЛИБРОКОМ. 367 с.

Суперанская А. В., Подольская Н. В., Васильева Н. В., 2009. Общая терминология : Вопросы теории / отв. ред. Т. Л. Канделаки. Изд. 5-е. М. : ЛИБРОКОМ. 248 c.

Суперанская А. В., Сталтмане В. Э., Подольская Н. В., Султанов А. Х., 2009. Теория и методика ономастических исследований / отв. ред. А. П. Непокупный. Изд. 3-е. М. : ЛИБРОКОМ. 256 с.

Супрун В. И., 2011. Размышления над ономастической терминологией // Известия Волгоградского государственного педагогического университета. № 8 (62). С. 133-138.

Феоктистова Л. А., 2016. К методике анализа ассоциативно-деривационной семантики личного имени // Вопросы ономастики. Т. 13, № 1. C. 85-116.

Хомутова Т. Н., 2008. Язык для специальных целей (LSP): лингвистический аспект // Известия Российского государственного педагогического университета им. А.И. Герцена. № 71. C. 96-106.
Юдина Н. В., 2010. Русский язык в XXI веке: кризис? эволюция? прогресс? М. : Гнозис. 293 с.

\section{ИСТОЧНИКИ}

Бурдаков - Бурдаков Н. С. Записки ветерана-атомщика. Озерск : Ред.-изд. центр ВРБ, 2009. 256 с.

Новоселов, Носач, Ентяков - Новоселов В. Н., Носач В. Ф., Ентяков Б. Н. Атомное сердце России. Челябинск : Автограф, 2014. 528 с.

Россия - Россия. Большой лингвострановедческий словарь / под общ. ред. Ю. Е. Прохорова. М. : АСТ-ПРЕСС КНИГА, 2009. 736 c.

Трякин - Трякин П. И. Аннушка // Творцы ядерного щита / отв. ред. П. И. Трякин. Озерск : Маяк, $1998.444 \mathrm{c}$.

Консорциум «Кодекс». URL: http:/docs.cntd.ru/ document/902193080 (дата обращения: 26.01.2018).

Международное агентство по атомной энергии. URL: https://www.iaea.org/ru.

Росатом. URL: http://www.biblioatom.ru/ (дата обращения: 26.01.2018)

Astronet. URL: http://www.astronet.ru/db/msg/1170734/ spacecraft.html (date of access: 26.01.2018).

European Nuclear Society. URL: https://www. euronuclear.org/ (date of access: 26.01.2018).

SpaSecraftrocket.org. URL: https://www. spasecraftrocket. org/chronology_spacecrafts.html (date of access: 26.01.2018).

The Story of Nukey Poo. URL: http://maisonbisson. com/post/15797/the-story-of-nukey-poo/ (date of access: 26.01 .2018$)$.

Wikipedia. URL: https://en.wikipedia.org/wiki/List_ of_nuclear_reactors (date of access: 26.01.2018).

World Nuclear Association. URL: https://www.worldnuclear.org/ (date of access: 26.01.2018).

\section{REFERENCES}

Berezovich E.L., 2010. Russkaya toponimiya v etnolingvisticheskom aspekte: Mifopoeticheskiy obraz prostranstva [Russian Toponymy in the Ethnolinguistic Aspect: Mythopoetic Image of Space]. Moscow, KomKniga Publ. 240 p.

Gudkov D.B., 1999. Pretsedentnoe imya i problemy pretsedentnosti [Precedent Proper Name and Aspects of Precedence]. Moscow, Izd-vo MGU. $152 \mathrm{p}$.

Krasnykh V.V., 2016. Slovar i grammatika lingvokultury. Osnovy psikholingvokulturologii [Vocabulary and Grammar of Linguoculture. Principles of Psycholinguistics Culturology]. Moscow, Gnozis Publ. 496 p. 
Kubryakova E.S., 2004. Yazyk i znanie: Na puti polucheniya znaniy o yazyke: Chasti rechi s kognitivnoy tochki zreniya. Rol yazyka $v$ poznanii mira [Language and Knowledge: Acquiring of Language Knowledge: Parts of Speech in the Cognitive Aspect. The Role of Language in the Worldview]. Moscow, Yazyki slavyanskoy kultury Publ. 560 p.

Kubryakova E.S., 2009. V poiskakh sushchnosti yazyka [In Search of the Essence of the Language]. Voprosy kognitivnoy lingvistiki [Issues of Cognitive Linguistics], no. 1 (18), pp. 5-12.

Leychik V.M., 2009a. Terminovedenie: Predmet, metody, struktura [Terminology Studies: Subject, Methods, Structure]. Moscow, LIBROKOM Publ. 256 p.

Leychik V.M., 2009b. Lyudi i slova: Kak rozhdayutsya $i$ zhivut slova $v$ russkom yazyke [People and Words: How Words Are Generated and Developed in Russian]. Moscow, LIBROKOM Publ. $216 \mathrm{p}$.

Makhniboroda O.V., 2007. Oklassifikatsii neofitsialnykh dopolnitelnykh imen neodushevlennykh predmetov [Classification of Informal Additional Names of Inanimate Objects]. Izvestiya Rossiyskogo gosudarstvennogo pedagogicheskogo universiteta im. A.I. Gertsena [Izvestia: Herzen University Journal of Humanities \& Sciences], no. 19 (45),pp. 155-158.

Podolskaya N.V., 1978. Slovar russkoy onomasticheskoy terminologii [Dictionary of Russian Onomastic Terminology]. Moscow, Nauka Publ. 198 p.

Rut M.E., 2003. Nominatsiya, narechenie i imya sobstvennoe [Nomination, Appellation and Proper Name]. Onomastika i dialektnaya leksika: sb. nauch. tr. [Onomastics and Dialectal Vocabulary. Collection of Scientific Works]. Yekaterinburg, Izd-vo Uralskogo universiteta, iss. 4, pp. 120-124.

Rut M.E., 2015. Onomasiologiya? Motivatsiya? Semantika? Ideografiya? O klassifikatsiyakh imen sobstvennykh [Onomasiology? Motivation? Semantics? Ideography? About classifications of Proper Names]. Etnolingvistika. Onomastika. Etimologiya: materialy III Mezhdunar. nauch. konf. (g. Ekaterinburg, 7-11 sent. 2015) [Ethnolinguistics. Onomatology. Etymology. Proceedings of the $3^{\text {rd }}$ International Scientific Conference (Yekaterinburg, September 7-11, 2015)]. Yekaterinburg, Izd-vo Uralskogo universiteta, pp. 231-233.

Sorokina E.A., 2016. Yazyk dlya spetsialnykh tseley kak sredstvo obshcheniya [Language for Special
Purposes as a Means of Communication]. Vestnik Chelyabinskogo gosudarstvennogo universiteta [Bulletin of Chelyabinsk State University], no. 4 (386), iss. 100, pp. 169-172.

Superanskaya A.V., 2009. Obshchaya teoriya imeni sobstvennogo [General Theory of Proper Name]. Moscow, LIBROKOM Publ. 367 p.

Superanskaya A.V., 2009. Podolskaya N.V., Vasilyeva N.V. Obshchaya terminologiya: Voprosy teorii [General Terminology: Theory Aspects]. Moscow, LIBROKOM Publ. 248 p.

Superanskaya A.V., Staltmane V.E., Podolskaya N.V., Sultanov A.H., 2009b. Teoriya i metodika onomasticheskikh issledovaniy [Theory and Methodology of Onomastic Research]. Moscow, LIBROKOM Publ. 256 p.

Suprun V.I., 2011. Razmyshleniya nad onomasticheskoy terminologiey [Reflection on Onomastic Terminology]. Izvestiya Volgogradskogo gosudarstvennogo pedagogicheskogo universiteta [Ivzestia of the Volgograd State Pedagogical University], no. 8 (62), pp. 133-138.

Feoktistova L.A., 2016. K metodike analiza assotsiativno-derivatsionnoy semantiki lichnogo imeni [Towards a Methodology for the Analysis of Associative-Derivational Meaning of a Personal Name]. Voprosy onomastiki [Problems of Onomastics], vol. 13, no.1, pp. 85-116.

Khomutova T.N., 2008. Yazyk dlya spetsialnykh tseley (LSP): lingvisticheskiy aspekt [Language for Special Purposes (LSP): Linguistic Aspect]. Izvestiya Rossiyskogo gosudarstvennogo pedagogicheskogo universiteta im. A.I. Gertsena. [Izvestia: Herzen University Journal of Humanities \& Sciences], no. 71, pp. 96-106.

Yudina N.V., 2010. Russkiy yazyk v XXI veke: krizis? evolyutsiya? progress? [Russian Language in the $21^{\text {st }}$ Century: Crisis? Evolution? Progress?]. Moscow, Gnozis Publ. 293 p.

\section{SOURCES}

Burdakov N.S. Zapiski veterana-atomshchika [Memoirs of a Nuclear Veteran]. Ozersk, Redaktsionno-izdatelskiy tsentr VRB, 2009. $256 \mathrm{p}$.

Novoselov V.N., Nosach V.F., Entyakov B.N. Atomnoe serdtse Rossii [The Atomic Heart of Russia]. Chelyabinsk, AvtografPubl., 2014. 528 p.

Prokhorova Yu.E., ed. Rossiya. Bolshoy lingvostranovedcheskiy slovar [Russia. Big Linguosocial Dictionary]. Moscow, AST-PRESS KNIGA Publ., 2009. 736 p. 


\section{МАТЕРИАЛЫ И СООБЩЕНИЯ}

Tryakin P.I. Annushka. Tryakin P.I., ed. Tvortsy yadernogo shchita [Creators of the Nuclear Shield]. Ozersk, Mayak Publ.,1998. 444 p.

Konsortsium «Kodeks» [“Kodeks" Consortium]. URL: http://docs.cntd.ru/document/902193080 (accessed 26 January 2018).

Mezhdunarodnoe agentstvo po atomnoy energii [International Atomic Energy Agency]. URL: https://www.iaea.org/ru.

Rosatom. URL: http://www.biblioatom.ru/ (accessed 26 January 2018).

Astronet. URL: http://www.astronet.ru/db/msg/1170734/ spacecraft.html (accessed 26 January 2018).
European Nuclear Society. URL: https://www. euronuclear.org/ (accessed 26 January 2018).

SpaSecraftrocket.org. URL: https://www. spasecraftrocket. org/chronology_spacecrafts.html (accessed 26 January2018).

The Story of Nukey Poo. URL: http://maisonbisson. com/post/15797/the-story-of-nukey-poo/ (accessed 26 January 2018).

Wikipedia. URL: https://en.wikipedia.org/wiki/ List_of_nuclear_reactors (accessed 26 January 2018).

World Nuclear Association. URL: https://www.worldnuclear.org/ (accessed 26 January 2018).

\section{Information about the Authors}

Natalya V. Yudina, Doctor of Sciences (Philology), Professor, Department of Language Training, Vice-Rector Deputy for Authorities Cooperation, Regional Development, Financial University under the Government of the Russian Federation, Prosp. Leningradsky, 49, GSP-3, 125993 Moscow, Russia, dr.yudina@mail.ru, https://orcid.org/0000-0002-7305-6959

Nataliya B. Feldman, Postgraduate Student, Department of the Russian Language, Vladimir State University named after A.G. and N.G. Stoletovs, Gorkogo St., 87, 600000 Vladimir, Russia; Coordinator of Special Projects, Vladimir Information Center of Nuclear Energy, Prosp. Oktyabrskiy, 3, 600000 Vladimir, Russia, nbfeldman@yandex.ru, https://orcid.org/0000-0002-0354-3778

\section{Информация об авторах}

Наталья Владимировна Юдина, доктор филологических наук, профессор департамента языковой подготовки, заместитель первого проректора по работе с органами власти и региональному развитию, Финансовый университет при Правительстве РФ, просп. Ленинградский, 49, ГСП-3, 125993 г. Москва, Россия, dr.yudina@mail.ru, https://orcid.org/0000-0002-7305-6959

Наталия Борисовна Фельдман, аспирант кафедры русского языка, Владимирский государственный университет им. А.Г. и Н.Г. Столетовых, ул. Горького, 87, 600000 г. Владимир, Россия; координатор специальных проектов, Информационный центр по атомной энергии г. Владимира, просп. Октябрьский, 3, 600000 г. Владимир, Россия, nbfeldman@yandex.ru, https://orcid.org/0000-0002-0354-3778 